\title{
Physicochemical and Microbiological Analysis of Stingless Bees Honey Collected from Local Market in Malaysia
}

\author{
Wan Nadja Julika ${ }^{1}$, Azilah Ajit ${ }^{1, *}$, Ahmad Ziad Sulaiman ${ }^{1}$, and Aishath Naila ${ }^{2}$ \\ ${ }^{1}$ Faculty of Chemical and Natural Resources Engineering, Universiti Malaysia Pahang, \\ Lebuhraya Tun Razak, 26300 Gambang, Pahang, Malaysia \\ ${ }^{2}$ Maldives National University, Central Administration, Rehdebai Hingun, Machangolhi, Male', Maldives
}

\section{*Corresponding author:}

email: azilahajit@ump.edu.my

Received: June 25, 2018

Accepted: December 11, 2018

DOI: $10.22146 / \mathrm{ijc} .40869$

\begin{abstract}
The growing demand for honey in the market has led to the occurrence of the tampering honey with foreign substances and increases the production of artificial honey. Due to this concern, this study works on the physicochemical and microbial characterization of stingless bee honey. The physicochemical analysis showed that the honey possessed $\mathrm{pH}$ (2.51-3.26), free acidity (121.1 to $318.7 \mathrm{meq} / \mathrm{kg}$ ), moisture (19.4$30.9 \%)$, electrical conductivity $(0.33-0.69 \mathrm{mS} / \mathrm{cm})$, ash content $(2.75-4.31 \mathrm{~g} / 100 \mathrm{~g})$, Hydroxymethylfurfural (HMF) content (35.4 to $461.7 \mathrm{mg} / \mathrm{kg}$ ) and diastase activity $(2.71$ to $6.11 \mathrm{DN})$. Also, sugar profile of honey showed that the honey contained fructose (15.03$32.52 \mathrm{~g} / 100 \mathrm{~g})$, glucose (12.17-34.55 g/100g) and sucrose $(0.01-7.29 \mathrm{~g} / 100 \mathrm{~g})$. The harvested honey, $\mathrm{H} 1$, and $\mathrm{H} 2$ have the highest potential to become an antibacterial agent to treat disease compared to commercial honey samples because they were active against gram-negative bacteria. All analyzed samples were within the maximum limit of the quality criteria set by the Malaysian Kelulut Standard and Codex Alimentarius except for free acidity, HMF, and Diastase Number. All the data obtained is vital in order to create a specific statute for stingless bees honey in Malaysia that may help to protect the consumer from purchasing adulterated honey.
\end{abstract}

Keywords: honey; adulteration; physicochemical; microbiological; quality

\section{- INTRODUCTION}

Stingless bees are small, all black creatures that commonly reside in the tropical and subtropical regions of the world, such as Southeast Asia and tropical America. Stingless bees are very special insects as they can produce three different products; honey, propolis, and bee bread. In addition, stingless bees are also valued as an effective pollinator for both wild and cultivated crops [1]. Honey is a natural sweetener that is widely used for various applications where it contains approximately 200 distinct chemical compositions including $80-85 \%$ of carbohydrates such as fructose and glucose [2]. Besides that, water, proteins, and amino acids, ash, hint of enzymes, vitamins and phenolic compounds also constitute almost 15-20\% in honey [2]. Nevertheless, the contents of honey differ depending on the types of plants as well as the nectar which the bee consumes [2].
The authenticity of honey is specified internationally by the Codex Alimentarius and European Legislation while locally; stingless bee honey is defined by Malaysian Standard Kelulut (Stingless Bee). The characterizations of honey, especially by physicochemical analyses, are well described by both standards [3]. Moisture content is the most popular criterion for stingless bees honey followed by free acidity, sugar profile, $\mathrm{pH}, \mathrm{HMF}$, ash content and electrical conductivity [4]. The moisture content was important as it influenced many other parameters in honey such as sugar content, hydroxymethylfurfural (HMF) and microbial properties. Based on the past studies, stingless bee honey has been reported to have a higher moisture content, higher electrical conductivity, lower enzyme activity, higher free acidity, and lower glucose and fructose content compared to Apis mellifera honey [4,32]. 
Microorganisms may influence the quality or safety of honey. Yeast and spore-forming bacteria are mostly found in honey, but to our concern, there are no bacteria causing disease had been identified in honey [5]. Microbial contaminations commonly occur in honey are from primary sources where it is difficult to control. The sources include pollen and nectar sources, the digestive system of honey bees, dirt, air and soil [6]. Good manufacturing practices may be the practical way to control the sources of contagion that are mostly found in secondary sources particularly from honey post-harvest including air, food operators, cross-contamination, equipment, and buildings [6-7].

Honey adulteration refers to the immoral act of producers by adding sugar syrups into natural product [8]. Commonly, adulterants such as water, sucrose, inverted sugar, hydroxymethyl cellulose, dextrin, and starch have been detected by routine analysis of physicochemical [9-10]. Adulteration activity of honey has increased the awareness among the honey consumers about the quality and purity of the commercial honey in the market. Thus, the study aimed to assess the quality of harvested honey and commercial stingless bee honey available in Malaysia market concerning the physicochemical properties and microbial profile.

\section{- EXPERIMENTAL SECTION}

\section{Materials}

In this study, six samples of stingless bees honey were collected from different regions in Malaysia (Table 1). Two samples, $\mathrm{H} 1$ and $\mathrm{H} 2$, were harvested from Universiti Malaysia Pahang stingless bee farm and Aqif Kelulut Farm, Pekan. Four samples of commercial stingless bee honey were randomly obtained from the local market around Malaysia.
All of the chemicals and reagents used were of analytical grade. Sugar standard (fructose, glucose, sucrose), acetonitrile, ethanol, sodium bisulfate, acetate buffer and sodium hydroxide $(\mathrm{NaOH})$, were purchased from Sigma-Aldrich (USA). Carrez solution I and II were purchased from Merck (Germany). Sodium chloride and iodine were obtained from $R \& M$ (Malaysia). Plate count agar (PCA), violet red bile glucose agar (VRGB), Sabouroud Dextrose agar (SDA) and Mueller Hinton agar were purchased from Oxoid, UK. Finally, chloramphenicol was obtained from Nacalai Tesque (Japan).

Two strains of the gram-positive bacteria and gram-negative bacteria: Escherichia coli and Bacillus sp. used in this study were obtained from the Central Laboratory, University Malaysia Pahang. The isolates were identified based on standard microbiological techniques, and sub-cultured in nutrient agar slopes at $37^{\circ} \mathrm{C}$ for $24 \mathrm{~h}$.

\section{Instrumentation}

Instrumentation used were SevenCompact $\mathrm{pH}$ meter (Mettler Toledo, USA), Hand-held refractometer (RHB 90ATC, China), Hi 8733 conductivity meter (Hanna Instruments, USA), Carbolite CWF 1200 muffle furnace ( Carbolite Gero Limited, UK), GENESYS 10S UV-Vis spectrophotometer (ThermoFisher Scientific, USA), LP vortex mixer (ThermoFisher Scientific, USA), 1260 Infinity II LC System (Agilent Technologies, USA), BS -21 shaking water bath (Lab Companion, Jaio Tech, South Korea) and Incubator I (Memmert, Germany).

\section{Procedure}

\section{Physicochemical analyses}

Determination of $\mathrm{pH}$ and moisture content. The $\mathrm{pH}$ of the honey sample was measured by diluting $10 \mathrm{~g}$ of

Table 1. Sampling location, description and time collection of six samples of stingless bee honey from Malaysia

\begin{tabular}{llll}
\hline Sample Code & Description & Sampling Location & Time of collection \\
\hline H1 & Harvested honey & Pahang & March 2017 \\
H2 & Harvested honey & Pahang & March 2017 \\
H3 & Commercial honey & Selangor & October 2017 \\
H4 & Commercial honey & Kedah & October 2017 \\
H5 & Commercial honey & Kuala Lumpur & November 2017 \\
H6 & Commercial honey & Pahang & September 2017 \\
\hline
\end{tabular}


of honey with $75 \mathrm{~mL}$ of distilled water while moisture content was determined by dropping approximately 1 to $2 \mathrm{~mL}$ of honey samples to the measuring surface of the handheld refractometer.

Determination of free acidity. The free acidity was measured by diluting $10 \mathrm{~g}$ of honey in $75 \mathrm{~mL}$ of distilled water before this solution was titrated with $0.1 \mathrm{M} \mathrm{NaOH}$ solution. $\mathrm{pH}$ readings were observed simultaneously during titration until the $\mathrm{pH}$ reached 8.5 , and the results were expressed in $\mathrm{mmol} / \mathrm{L}$.

\section{Determination of electrical conductivity and ash} content. The electrical conductivity was measured by diluting $20 \mathrm{~g}$ of honey in $100 \mathrm{~mL}$ distilled water $(20 \% \mathrm{w} / \mathrm{w})$ where the results were expressed in milliSiemens per centimeter $(\mathrm{mS} / \mathrm{cm})$. The honey ash content was determined by placing the crucible in an oven for $1 \mathrm{~h}$. After cooling, the crucible was weighed, and $5 \mathrm{~g}$ of the honey sample was added into the crucible before burnt in a $500{ }^{\circ} \mathrm{C}$ furnace for $2 \mathrm{~h}$ until constant mass was obtained. The sample was then reweighed, and ash percentage was calculated.

Determination of hydroxymethylfurfural (HMF). Determination of HMF was carried out by following the International Honey Commission's harmonized methods [11] where $5 \mathrm{~g}$ of honey sample was weighed and completely dissolved in $25 \mathrm{~mL}$ of distilled water. The volumetric flask containing a honey solution was added with $0.5 \mathrm{~mL}$ Carrez solution I and mixed well by vortex. The mixed solution was then added with $0.5 \mathrm{~mL}$ Carrez solution II and mixed before adding distilled water up to $50 \mathrm{~mL}$ mark. A drop of ethanol was added to suppress the foam that formed during mixing. The first $10 \mathrm{~mL}$ of the mixture was disposed of after being filtered through filter paper. $5.0 \mathrm{~mL}$ of the solution was placed in two test tubes where in Tube 1 (sample solution) was added with $5.0 \mathrm{~mL}$ of distilled water and in Tube 2 (reference solution) was added with $5.0 \mathrm{~mL}$ of $0.2 \%$ sodium bisulfate solution. The absorbance of the solutions was recorded at 284 and $336 \mathrm{~nm}$, respectively.

Determination of sugar profile. The determination of sugar (fructose, glucose, sucrose) were performed following the method of Malaysian Kelulut Standard [12]. The sugars were eluted through Phenomenex column
(PhenoSphere $5 \mu \mathrm{NH}_{2} 80 \mathrm{~A}, 250 \times 4.6 \mathrm{~mm}$, Phenomenex Inc, USA) and detected by Refractive Index detector (RID) operated at $40^{\circ} \mathrm{C}$. The mobile phase is acetonitrile: water $(80: 20, \mathrm{v} / \mathrm{v})$ at a flow rate of $1.3 \mathrm{~mL} / \mathrm{min}$. The retention times obtained from the standards were compared to obtain HPLC sample peaks. The injections were performed in triplicate where the average peak area was used for evaluation.

Determination of diastase activity. The diastase activity of honey was determined by dissolving $5.0 \mathrm{~g}$ of honey in $15 \mathrm{~mL}$ distilled water and $2.5 \mathrm{~mL}$ of acetate buffer (1.59 M, pH 5.3). The samples solution was then mixed with $1.5 \mathrm{~mL}$ of $0.5 \mathrm{M} \mathrm{NaCl}$ solution before $10 \mathrm{~mL}$ of this solution was transferred in a test tube containing $5 \mathrm{~mL}$ of $2 \%$ starch solution. The test tube was then kept in a water bath at $40{ }^{\circ} \mathrm{C}$ for $5 \mathrm{~min}$, and $1 \mathrm{~mL}$ of the solution was added with $10 \mathrm{~mL}$ of $0.0007 \mathrm{M}$ diluted iodine solution. The absorbance was recorded at $660 \mathrm{~nm}$ in spectrophotometer until readings showed absorbance less than 0.235 . The diastase activity was expressed in Gothe degrees. DN was the amount of enzyme that hydrolyzed/converts $1 \%$ starch solution/0.01g of starch for $1 \mathrm{~h}$ at $40^{\circ} \mathrm{C}$.

\section{Microbiological analyses}

Standard plate count. The honey samples that were diluted in saline water were plated on standard plate count agar and incubated at $30^{\circ} \mathrm{C}$ for $48 \mathrm{~h}$.

Detection of Bacillus sp. The initial dilution containing the aerobic spore-forming bacteria was heated in 10 minutes at $80{ }^{\circ} \mathrm{C}$ and immediately immersed in cold water afterward to cool down the temperature. Bacillus sp.

was detected by plating the dilutions on plate count agar (PCA) and incubated at $30^{\circ} \mathrm{C}$ for $48 \mathrm{~h}$.

Detection of total coliform. The samples were plated on violet red bile glucose agar (VRGB) and incubated at $35^{\circ} \mathrm{C}$ for $48 \mathrm{~h}$.

Yeast and Moulds count. Yeast and Moulds were quantified after plating the samples on Sabouroud Dextrose agar (SDA) supplemented by $100 \mathrm{mg} / \mathrm{L}$ chloramphenicol. The plates were incubated at $25^{\circ} \mathrm{C}$ for 5 days. Microbial counts were expressed as colonyforming units per gram of honey sample ( $\mathrm{cfu} / \mathrm{g})$. 


\section{Antibacterial analysis: Agar disc diffusion method}

The agar diffusion method was determined by following the method by Moussa [13]. Fresh culture suspension of the test microorganisms $(100 \mu \mathrm{L})$ was spread on Mueller Hinton agar. The concentration of cultures was $1 \times 10^{7} \mathrm{CFU} / \mathrm{mL}$. For screening, $5 \mathrm{~mm}$ sterile diameter filter paper disc was infused with $10 \mu \mathrm{L}$ of honey equivalent to $0.1 \mathrm{mg}$ of honey. The plates were placed at $4{ }^{\circ} \mathrm{C}$ for $2 \mathrm{~h}$ before being incubated under optimum conditions for $24 \mathrm{~h}$. Clear inhibition zones around the discs indicated the presence of antimicrobial activity. The zone diameters of inhibition (ZDI) was measured in millimeter, including the diameter of the disc. The controls were set up with equivalent quantities of water as a control.

\section{Statistical analysis}

All analyses were prepared in triplicate. The data obtained in the study were analyzed using analysis of variance (ANOVA) and followed by Tukey test (Minitab 18, Minitab Inc., USA) where the differences between mean values were significant at values of $\mathrm{p}<0.05$.

\section{- RESULTS AND DISCUSSION}

\section{Physicochemical Analyses}

Table 2 reported the physicochemical properties of the different samples of honey obtained from a local market in Malaysia. According to the result, $\mathrm{pH}$ values ranged from 2.51 to 3.26 which met the criteria of pure honey. There was no significant difference in the $\mathrm{pH}$ values of $\mathrm{H} 1$ and $\mathrm{H} 2(\mathrm{p}>0.05)$. However, when compared with $\mathrm{H} 3, \mathrm{H} 4$, and $\mathrm{H} 5$, the results were significantly different. The $\mathrm{pH}$ values varied depending on their geographical origin, floral sources as well as the bee's species [14]. Honey from warm and humid countries usually has lower $\mathrm{pH}$ due to their high water content. The $\mathrm{pH}$ of adulterated honey is higher (more than $\mathrm{pH}$ 5.5) compared to pure honey due to the extraction, storage factor, and temperature of honey [7].

From the result, six selected honey samples showed that the percentage of moisture content fluctuated from 19.4 to $30.9 \%$ which is still in the range of Malaysian Kelulut standard. The variation may be due to the humidity of tropical forest, floral origin, soil, collection period and processing aspects [14-15]. $\mathrm{H} 2$ has the highest moisture content while $\mathrm{H} 4$ has the lowest moisture content. This may be due to the collection time of $\mathrm{H} 2$ which was during the rainy season while $\mathrm{H} 4$ may have undergone moisture removal. Besides increasing the probability of fermentation happening, higher moisture content (more than $35 \%$ ) can also indicate that the honey is adulterated [16-17].

Typically, a small amount of acid can be found in pure honey which is significant for a taste of honey [18]. From the result, $\mathrm{H} 4$ has the highest free acidity with a value of $318.7 \mathrm{meq} / \mathrm{kg}$. There is no fixed limit of free acidity in Malaysian Kelulut standard, but all six samples

Table 2. Summary of physicochemical analyses of six sample of stingless bee honey from Malaysia (mean \pm standard deviation, $\mathrm{n}=3$ )

\begin{tabular}{|c|c|c|c|c|c|c|c|c|c|c|}
\hline Sample & $\mathrm{pH}$ & $\begin{array}{c}\text { Moisture } \\
(\%)\end{array}$ & $\begin{array}{c}\text { F.A } \\
\text { (meq/kg) }\end{array}$ & $\begin{array}{c}\mathrm{EC} \\
(\mathrm{mS} / \mathrm{cm})\end{array}$ & $\begin{array}{c}\text { Ash } \\
(\mathrm{g} / 100 \mathrm{~g})\end{array}$ & $\begin{array}{c}\text { HMF } \\
(\mathrm{mg} / \mathrm{kg})\end{array}$ & $\begin{array}{c}\text { Diastase } \\
\text { Number } \\
(\mathrm{DN})\end{array}$ & $\begin{array}{l}\text { Fructose } \\
(\mathrm{g} / 100 \mathrm{~g})\end{array}$ & $\begin{array}{l}\text { Glucose } \\
(\mathrm{g} / 100 \mathrm{~g})\end{array}$ & $\begin{array}{l}\text { Sucrose } \\
(\mathrm{g} / 100 \mathrm{~g})\end{array}$ \\
\hline $\mathrm{H} 1$ & $3.26 \pm 0.11^{\mathrm{a}}$ & $25.4 \pm 0.09^{d}$ & $146.4 \pm 7.46^{b}$ & $0.56 \pm 0.01^{b}$ & $3.11 \pm 0.23^{\mathrm{a}}$ & $74.3 \pm 6.88^{b}$ & $5.97 \pm 0.18^{\mathrm{a}}$ & $17.5 \pm 1.3^{\mathrm{a}}$ & $16.0 \pm 0.8^{b}$ & $<0.01$ \\
\hline $\mathrm{H} 2$ & $3.20 \pm 0.08^{\mathrm{a}}$ & $30.9 \pm 0.06^{\mathrm{a}}$ & $121.1 \pm 1.24^{\mathrm{b}}$ & $0.33 \pm 0.01^{\mathrm{c}}$ & $0.72 \pm 0.11^{\mathrm{b}}$ & $85.9 \pm 8.40^{\mathrm{b}}$ & $5.85 \pm 0.08^{a}$ & $15.03 \pm 1.22^{\mathrm{a}}$ & $12.17 \pm 0.47^{\mathrm{b}}$ & $<0.01$ \\
\hline H3 & $2.52 \pm 0.03^{c}$ & $23.4 \pm 0.53^{\mathrm{e}}$ & $257.8 \pm 2.39^{a}$ & $0.68 \pm 0.01^{\mathrm{a}}$ & $2.75 \pm 1.12^{\mathrm{a}}$ & $457.2 \pm 0.81^{\mathrm{a}}$ & $2.32 \pm 0.12^{b}$ & $30.96 \pm 0.81^{b}$ & $31.6 \pm 0.79^{a}$ & $1.10 \pm 0.03^{\mathrm{a}}$ \\
\hline $\mathrm{H} 4$ & $2.79 \pm 0.01^{b}$ & $28.4 \pm 0.51^{b}$ & $318.7 \pm 77.6^{a}$ & $0.40 \pm 0.03^{\mathrm{c}}$ & $3.86 \pm 1.02^{\mathrm{a}}$ & $35.4 \pm 0.71^{\mathrm{c}}$ & $6.30 \pm 1.16^{a}$ & $32.52 \pm 0.59^{b}$ & $30.09 \pm 0.70^{\mathrm{a}}$ & $<0.01$ \\
\hline H5 & $2.51 \pm 0.01^{\mathrm{c}}$ & $19.4 \pm 0.21^{\mathrm{f}}$ & $250.7 \pm 3.19^{a}$ & $0.69 \pm 0.06^{\mathrm{a}}$ & $4.31 \pm 1.53^{\mathrm{a}}$ & $461.7 \pm 5.69^{a}$ & $2.16 \pm 0.13^{b}$ & $31.64 \pm 0.48^{b}$ & $34.55 \pm 0.50^{\mathrm{a}}$ & $2.81 \pm 0.09^{\mathrm{a}}$ \\
\hline H6 & $2.57 \pm 0.01^{\mathrm{c}}$ & $26.7 \pm 0.61^{\mathrm{c}}$ & $241.7 \pm 3.46^{\mathrm{a}}$ & $0.65 \pm 0.04^{\mathrm{a}}$ & $0.52 \pm 0.16^{\mathrm{b}}$ & $456.6 \pm 2.72^{a}$ & $2.79 \pm 0.01^{\mathrm{b}}$ & $22.83 \pm 0.42^{c}$ & $25.47 \pm 0.50^{c}$ & $7.29 \pm 0.18^{b}$ \\
\hline Mean \pm SD & $2.81 \pm 0.34$ & $25.7 \pm 4.01$ & $222.7 \pm 74.5$ & $0.55 \pm 0.15$ & $2.54 \pm 1.58$ & $261.8 \pm 216.1$ & $4.23 \pm 2.0$ & $25.08 \pm 7.70$ & $24.98 \pm 9.02$ & $3.73 \pm 3.20$ \\
\hline Min Value & 2.51 & 19.4 & 121.1 & 0.33 & 0.52 & 35.4 & 2.16 & 15.03 & 12.17 & $<0.01$ \\
\hline Max Value & 3.26 & 30.9 & 257.8 & 0.69 & 4.31 & 461.7 & 6.30 & 32.52 & 34.55 & 7.29 \\
\hline
\end{tabular}

Note: ${ }^{a-f}=$ Means with a different superscript letter along the column are significantly different (p < 0.05); F.A: Free acidity; EC: Electrical conductivity; HMF: Hydroxymethylfurfural 
acid values exceeded the international honey standard, which is no more than $50 \mathrm{meq} / \mathrm{kg}$. This may explain the sour taste that the stingless bee exhibit. The lower value of acidity indicates the freshness of honey however the value may increase with time. This is due to the fermentation process where sugars converted into organic acids. [7,19]. Besides that, flower sources and bee species influence the variation of acidity value since it conforms to the balance of organic acids present in honey [15].

Electrical conductivity relies predominantly on the mineral content of honey [20]. From the six samples, H5 had the highest value of electrical conductivity with 0.69 $\pm 0.69 \mathrm{mS} / \mathrm{cm}$ which may indicate that the honey is rich in mineral content. The differences in electrical conductivity correspond to not only the different geographical and floral sources but also the number of organic acids, proteins and storage time [14,21]. The color of honey also influence the electrical conductivity values as dark honey gives higher conductivity due to higher levels of microelements than light honey [22].

From the result of ash, only $\mathrm{H} 2$ and $\mathrm{H} 6$ were observed to be within the range of Malaysian Kelulut standard $(<1.0 \mathrm{~g} / 100 \mathrm{~g})$ while others reported being higher. The high value of ash may contribute by the floral source and nectar characteristic in some floral species [23]. There is a wide distribution of values detected in all six samples which may contribute by an irregular pattern of harvest processes and the different in meliponiculture techniques used by the producers [24]. Ash content and electrical conductivity are closely related to the mineral content in honey, but ash is differing as it directly measures the inorganic residue after carbonization [25].

HMF is one of the indicators used to assess the quality of honey which is absent in fresh honey [26]. Results showed that H4 has the lowest HMF values (35.4 $\pm 0.71 \mathrm{mg} / \mathrm{kg}$ ) but still exceeded the limit set by the Malaysian Kelulut standard $(<30 \mathrm{mg} / \mathrm{kg})$. The samples $\mathrm{H} 3, \mathrm{H} 5$, and H6, exceeded the HMF limit in both international standard and Kelulut standard (> $400 \mathrm{mg} / \mathrm{kg}$ ) which suggest that the three honey samples have undergone a heating process or adulterated. Furthermore, high HMF content in honey also demonstrates the fabrication of honey with invert syrup since HMF can be formed by heating sugars in the presence of an acid to the inversion of sucrose [27-30]. Even though HMF of $\mathrm{H} 1, \mathrm{H} 2$, and $\mathrm{H} 4$ were quite high, the result may cause from poor storage condition, or the samples were old. The values of HMF could increase during processing, preparation, aging, and storage of honey [26].

In good quality honey, the fructose content should exceed the glucose content [16,31], except in three samples (H3, H5, and H6). Thus, H3, H5, and H6 probably had poor quality. Harvested honey samples, $\mathrm{H} 1$ and $\mathrm{H} 2$, had lower fructose and glucose content compared to other commercial samples but still comparable with the study of Thailand and Malaysian stingless bee honey [32-33]. Sucrose content should be within $8.0 \mathrm{~g} / 100 \mathrm{~g}$, and all analyzed samples were still within the Malaysian Kelulut standard limit. The high concentration of sucrose may due to the diversity of floral sources, early harvest of honey as the sucrose not fully transform into fructose and glucose, overfeeding the bees with sugars, syrups or artificial honey and lastly, the honey is adulterated by the addition of commercial sugar [14,34-35].

Denoted as Diastase Number (DN), diastase activity for six samples of honey ranged from 2.6 to 6.30 DN. There is no fixed limit for Diastase Number in Malaysian Kelulut standard, but according to international honey standard, Diastase Number should be no more than 3 for honey with low enzyme content. H3, H5, and H6 samples have low DN number (less than $3 \mathrm{DN}$ ) which may mean that these honey is aging or has been heated since enzymes are susceptible towards heat [36]. Diastase Number is not only controlled by geographical and botanical origin but also by $\mathrm{pH}$ values, nectar flow and foraging patterns of the bees [24-25].

\section{Microbiological Analyses}

The microbial counts of six stingless bee honey samples can be observed in Table 3. The standard plate counts (SPC) were found in every sample with a count of $1 \times 10^{2} \mathrm{cfu} / \mathrm{g}$ to $9.7 \times 10^{2} \mathrm{cfu} / \mathrm{g}$. The total plate counts variation may be influenced by the honey characteristic, honey freshness, the harvest period and infection by pathogenic bacteria $[6,25]$. The most common types of 
Table 3. Summary of the microbial profile of honey samples from Malaysia

\begin{tabular}{|c|c|c|c|c|c|}
\hline \multirow{2}{*}{ Sample } & \multicolumn{5}{|c|}{ Microbial count $\left(\times 10^{2} \mathrm{cfu} / \mathrm{g}\right)$} \\
\hline & SPC & Bacillus sp. & Total coliform & Yeast & Mold \\
\hline & $2.0 \times 10^{2}$ & & & & \\
\hline \multirow[t]{3}{*}{$\mathrm{H} 1$} & $1.5 \times 10^{2}$ & ND & $\mathrm{D}$ & $\mathrm{ND}$ & ND \\
\hline & $1.0 \times 10^{2}$ & & & & \\
\hline & $3.0 \times 10^{2}$ & & & & \\
\hline \multirow[t]{3}{*}{$\mathrm{H} 2$} & $8.0 \times 10^{2}$ & ND & ND & ND & ND \\
\hline & $4.4 \times 10^{2}$ & & & & \\
\hline & $3.6 \times 10^{2}$ & & & & \\
\hline \multirow[t]{3}{*}{$\mathrm{H} 3$} & $4.5 \times 10^{2}$ & $\mathrm{D}$ & $\mathrm{D}$ & $\mathrm{D}$ & $\mathrm{D}$ \\
\hline & $1.5 \times 10^{2}$ & & & & \\
\hline & $2.6 \times 10^{2}$ & & & & \\
\hline \multirow[t]{3}{*}{$\mathrm{H} 4$} & $2.7 \times 10^{2}$ & $\mathrm{D}$ & ND & $\mathrm{D}$ & $\mathrm{D}$ \\
\hline & $9.7 \times 10^{2}$ & & & & \\
\hline & $1.5 \times 10^{2}$ & & & & \\
\hline \multirow[t]{3}{*}{ H5 } & $2.2 \times 10^{2}$ & $\mathrm{D}$ & ND & $\mathrm{D}$ & $\mathrm{D}$ \\
\hline & $3.5 \times 10^{2}$ & & & & \\
\hline & $1.0 \times 10^{2}$ & & & & \\
\hline \multirow[t]{2}{*}{ H6 } & $1.0 \times 10^{2}$ & $\mathrm{D}$ & ND & ND & ND \\
\hline & $1.0 \times 10^{2}$ & & & & \\
\hline
\end{tabular}

SPC: Standard Plate Count; D = Detectable; ND=Not Detectable

Table 4. Summary of antibacterial activity of various honey samples on gram-positive and gram-negative bacteria

\begin{tabular}{llll}
\hline Sample & Dilution & Bacillus sp. $(\mathrm{mm})$ & E. coli $(\mathrm{mm})$ \\
\hline \multirow{2}{*}{ H1 } & Undilute & 15 & 11 \\
& $10^{-1}$ & - & - \\
& $10^{-2}$ & - & - \\
\hline \multirow{2}{*}{ H2 } & Undilute & 24 & 11 \\
& $10^{-1}$ & - & - \\
& $10^{-2}$ & - & - \\
\hline \multirow{3}{*}{ H3 } & Undilute & 20 & - \\
& $10^{-1}$ & - & - \\
& $10^{-2}$ & - & - \\
\multirow{2}{*}{ H4 } & Undilute & - & - \\
& $10^{-1}$ & - & - \\
& $10^{-2}$ & - & - \\
\hline \multirow{2}{*}{ H5 } & Undilute & 12 & - \\
& $10^{-1}$ & - & - \\
& $10^{-2}$ & - & - \\
\multirow{2}{*}{ H6 } & Undilute & 10 & - \\
& $10^{-1}$ & - & - \\
\hline
\end{tabular}

Bacillus sp. in honey are B. cereus, B. megaterium, $B$. coagulans, and B. pumilus [25]. Bacillus sp. were absence in $\mathrm{H} 1$ and $\mathrm{H} 2$ which may indicate that the honey is well conserved against this bacteria. The symbiotic relationship 


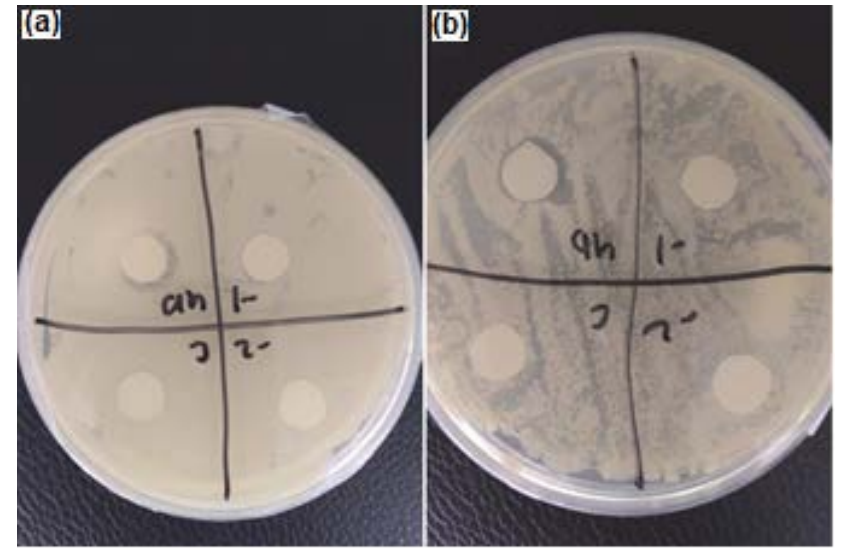

Fig 1. (a) The inhibition zone by using different dilution factor on E. coli (b) The inhibition zone by using different dilution factor on Bacillus sp.

between Bacillus $s p$ and insects especially tropical honey bees and stingless bees may be the solid reason why these bacteria were present in the other four samples [37]. Total coliform indicates the sanitary quality of honey [21], and for this study, the coliform was present only in $\mathrm{H} 1$ and $\mathrm{H} 3$ samples. The low counts and limited variety of microbes are expected because of honey antibacterial properties against the growth or persistence of many organisms $[31,38]$. Yeast and mold were not detected for $\mathrm{H} 1, \mathrm{H} 2$, and H6 but, it was present in a high number $(>100)$ for the other three samples. The result for $\mathrm{H} 3, \mathrm{H} 4$, and $\mathrm{H} 5$ contradict the limit set by Malaysia Kelulut standard where the count should be less than $1 \times 10^{1} \mathrm{cfu} / \mathrm{g}$.

\section{Antibacterial Analysis: Agar Disc Diffusion}

From Table 4, H1, and $\mathrm{H} 2$ had a greater inhibitory effect on both gram-negative (E. coli) and gram-positive bacteria (Bacillus sp.) when tested using undiluted honey. The results of commercial honey samples also showed they had an inhibitory effect only on gram-positive bacteria when tested using undiluted honey (except H4), but all the commercial honey samples were not active against gram-negative bacteria, E. coli. The disc diameter of harvested samples was ranged from 11 to $24 \mathrm{~mm}$ where commercial honey, $\mathrm{H} 3, \mathrm{H} 5$, and $\mathrm{H} 6$, ranged from 10 to $20 \mathrm{~mm}$. There were no zone diameters of inhibition (ZDI) was measured on $\mathrm{H} 4$ sample for both bacteria tested. Among all honey samples, $\mathrm{H} 1$ and $\mathrm{H} 2$ are the only honey that have effects on gram-negative bacteria. Thus, the honey may have the potential as therapeutic or healing honey [13]. The antibacterial activity of honey depends on various factors such as geographical origin, botanical source, harvesting (season when honey was collected), processes and storage conditions as well as the presence of hydrogen peroxide, phenolic compounds, acidity, phytochemicals, $\mathrm{pH}$ of honey and higher osmotic pressure $[13,25,39]$.

\section{- CONCLUSION}

In this present work, six samples honey from the local market in Malaysia have been analyzed for their quality criteria concerning the physicochemical parameters and microbial profile. All analyzed samples are within the maximum limit of the quality criteria set by the Malaysian Kelulut Standard and Codex Alimentarius except for free acidity, HMF, and Diastase Number. Most samples have a high value of HMF (more than $400 \mathrm{mg} / \mathrm{kg}$ ) and lower Diastase Number (lower than $3 \mathrm{DN}$ ) especially for $\mathrm{H} 3, \mathrm{H} 5$, and H6. These three samples may indicate poor honey processing and the possibility of adulteration. Even though $\mathrm{H} 1$ and $\mathrm{H} 2$ were purely harvested from the farm, the quality of both honey is quite poor which may be due to prolonged storage (more than six month) and the poor storage condition. There is no limit set by the Malaysian standard for free acidity, electrical conductivity, and Diastase Number. Hopefully, in future, these parameters can be added into the Malaysian Kelulut Standard to ensure the standard is as per with another international standard available. Honey is known for its antibacterial properties; however, microbial growth has been found in most samples, expressing poor hygienic procedures during harvesting, packaging or storage. Although this study was a preliminary work and only limited to six samples, more sample data are in preparation in order to be part of the process to create more specific legislation for stingless bees honey in Malaysia.

\section{- ACKNOWLEDGMENTS}

This study was financially supported by Universiti Malaysia Pahang (Grant no: RDU 170332). We also would like to thank meliponiculturists especially from 
Aqif Kelulut Farm, Pekan, Pahang for assisting us in the collection of stingless bee honey samples.

\section{- REFERENCES}

[1] Mathiasson, M.E., Kwapong, P.K., Wubah, D.A., and Wubah, J.A., 2015, Early colony development of an equatorial afrotropical stingless bee (Hypotrigona sp.) In a new habitat, J. Young Invest., 29 (3), 11-17.

[2] Rao, P.V., Krishnan, K.T., Salleh, N., and Gan, S.H., 2016, Biological and therapeutic effects of honey produced by honey bees and stingless bees: A comparative review, Braz. J. Pharmacogn., 26 (5), 657-664.

[3] Matović, K., Ćirić, J., Kaljević, V., Nedić, N., Jevtić, G., Vasković, N., and Baltić, M.Ž., 2018, Physicochemical parameters and microbiological status of honey produced in an urban environment in Serbia, Environ. Sci. Pollut. Res., 25 (14), 1414814157.

[4] Nordin, A., Sainik, N.Q.A.V., Chowdhury, S.R., Bin Saim, A., and Bt Hj Idrus, R., 2018, Physicochemical properties of stingless bee honey from around the globe: A comprehensive review, J. Food Compos. Anal., 73, 91-102.

[5] Adenekan, M.O., Amusa, N.A, Lawal, A.O., and Okpeze, V.E., 2010, Physico-chemical and microbiological properties of honey samples obtained from Ibadan, J. Microbiol. Antimicrob., 2 (8), 100-104.

[6] Snowdon, J.A., and Cliver, D.O., 1996, Microorganisms in honey, Int. J. Food Microbiol., 31 (1-3), 1-26.

[7] Gomes, S., Dias, L.G., Moreira, L.L., Rodrigues, P., and Estevinho, L., 2010, Physicochemical, microbiological and antimicrobial properties of commercial honeys from Portugal, Food Chem. Toxicol., 48 (2), 544-548.

[8] Islam, M.N., Khalil, M.I., Islam, M.A., and Gan, S.H., 2014, Toxic compounds in honey, J. Appl. Toxicol., 34 (7), 733-742.

[9] Gan, Z., Yang, Y., Li, J., Wen, X., Zhu, M., Jiang, Y., and Ni, Y., 2015, Using sensor and spectral analysis to classify botanical origin and determine adulteration of raw honey, J. Food Eng., 178, 151158.

[10] Serrano, S., Villarejo, M., Espejo, R., and Jodral, M., 2004, Chemical and physical parameters of Andalusian honey: Classification of Citrus and Eucalyptus honeys by discriminant analysis, Food Chem., 87 (4), 619-625.

[11] Bogdanov, S., 2009, Harmonised Methods of the International Honey Commision, Swiss Research Centre, FAM, Liebefeld.

[12] Malaysian Standard, 2017, Kelulut (Stingless bee) honey - Specification: MS 2683-2017, Department of Standard Malaysia., 67.180.10.

[13] Moussa, A., Noureddine, D., Abdelmelek, M., and Saad, A., 2012, Antibacterial activity of various honey types of Algeria against Pathogenic GramNegative Bacilli: Escherichia coli and Pseudomonas aeruginosa, Asian Pac. J. Trop. Dis., 2 (3), 211-214.

[14] de Sousa, J.M.B., de Souza, E.L., Marques, G., Benassi, M.T., Gullón, B., Pintado, M.M., and Magnani, M., 2016, Sugar profile, physicochemical and sensory aspects of monofloral honeys produced by different stingless bee species in Brazilian semiarid region, LWT Food Sci. Technol., 65, 645-651.

[15] Biluca, F.C., Braghini, F., Gonzaga, L.V., Costa, A.C.O., and Fett, R., 2016, Physicochemical profiles, minerals and bioactive compounds of stingless bee honey (Meliponinae), J. Food Compos. Anal., 50, 61-69.

[16] El Sohaimy, S.A., Masry, S.H.D., and Shehata, M.G., 2015, Physicochemical characteristics of honey from different origins, Ann. Agric. Sci., 60 (2), 279287.

[17] Gangwar, S., 2016, Honey physio-chemical parameters and its application with reference to Ethiopia, IJSN, 7 (1), 16-24.

[18] Bogdanov, S., and Gallman, P., 2008, Authenticity of honey and other bee products state of the art, ALP Sci., 520, 63-64.

[19] Yadata, D., 2014, Detection of the electrical conductivity and acidity of honey from different areas of Tepi, Food Sci. Technol., 2 (5), 59-63. 
[20] Taddia, M., Musiani, A., and Schiavi, S., 2004, Determination of heavy metals in honey by Zeeman electrothermal atomic absorption spectrometry, Ann. Chim., 94 (1-2), 107-111.

[21] Malika, N., Mohamed, F., and Chakib, E., 2005, Microbiological and physico-chemical properties of Moroccan honey, Int. J. Agric. Biol, 7 (5), 773-776.

[22] Alqarni, A.S., Owayss, A.A., Mahmoud, A.A., and Hannan, M.A., 2014, Mineral content and physical properties of local and imported honeys in Saudi Arabia, J. Saudi Chem. Soc., 18 (5), 618-625.

[23] Önür, İ., Misra, N.N., Barba, F.J., Putnik, P., Lorenzo, J.M., Gökmen, V., and Alpas, H., 2018, Effects of ultrasound and high pressure on physicochemical properties and HMF formation in Turkish honey types, J. Food Eng., 219, 129-136.

[24] Finola, M.S., Lasagno, M.C., and Marioli, J.M., 2007, Microbiological and chemical characterization of honeys from central Argentina, Food Chem., 100 (4), 1649-1653.

[25] Andualem, B., 2014, Physico-chemical, microbiological and antibacterial properties of Apis mellipodae and Trigona spp. honey against bacterial pathogens, World J. Agric. Sci., 10 (3), 112-120.

[26] Zappalà, M., Fallico, B., Arena, E., and Verzera, A., 2005, Methods for the determination of HMF in honey: A comparison, Food Control, 16 (3), 273-277.

[27] Capuano, E., and Fogliano, V., 2011, Acrylamide and 5-hydroxymethylfurfural (HMF): A review on metabolism, toxicity, occurrence in food and mitigation strategies, LWT Food Sci. Technol., 44 (4), 793-810.

[28] Yücel, Y., and Sultanoğlu, P., 2013, Characterization of honeys from Hatay Region by their physicochemical properties combined with chemometrics, Food Biosci., 1, 16-25.

[29] da Silva, P.M., Gauche, C., Gonzaga, L.V., Costa, A.C.O., and Fett, R., 2016, Honey: Chemical composition, stability and authenticity, Food Chem., 196, 309-323.

[30] Pasias, I.N., Kiriakou, I.K., and Proestos, C., 2017, HMF and diastase activity in honeys: A fully validated approach and a chemometric analysis for identification of honey freshness and adulteration, Food Chem., 229, 425-431.

[31] Buba, F., Gidado, A., and Shugaba, A., 2013, Physicochemical and microbiological properties of honey from North East Nigeria, Biochem. Anal. Biochem., 2, 142.

[32] Chuttong, B., Chanbang, Y., Sringarm, K., and Burgett, M., 2016, Physicochemical profiles of stingless bee (Apidae: Meliponini) honey from South East Asia (Thailand), Food Chem., 192, 149155.

[33] Kek, S.P., Chin, N.L., Tan, S.W., Yusof, Y.A., and Chua, L.S., 2017, Classification of honey from its bee origin via chemical profiles and mineral content, Food Anal. Methods, 10 (1), 19-30.

[34] Anklam, E., 1998, A review of the analytical methods to determine the geographical and botanical origin of honey, Food Chem., 63 (4), 549562.

[35] Suntiparapop, K., Prapaipong, P., and Chantawannakul, P., 2012, Chemical and biological properties of honey from Thai stingless bee (Tetragonula leaviceps), J. Apic. Res., 51 (1), 45-52.

[36] Iftikhar, F., Mahmood, R., Islam, N., Sarwar, G., Masood, M.A., and Shafiq, H., 2014, Physicochemical analysis of honey samples collected from local markets of Rawalpindi and Islamabad, Am. J. Biochem., 4 (2), 35-40.

[37] Pucciarelli, A.B., Schapovaloff, M.E., Kummritz, S., Señuk, I.A., Brumovsky, L.A., and Dallagnol, A.M., 2014, Microbiological and physicochemical analysis of yateí (Tetragonisca angustula) honey for assessing quality standards and commercialization, Rev. Argent. Microbiol., 46 (4), 325-332.

[38] Agbagwa, O.E., Otokunefor, T.V, and FrankPeterside, N., 2014, Preliminary detection of Bacillus species in commercial honey, Br. Microbiol. Res. J., 4 (12), 1370-1380.

[39] Yaacob, M., Rajab, N.F., Shahar, S., and Sharif, R., 2017, Stingless bee honey and its potential value: a systematic review, Food Res., 2 (2), 124-133. 